College of Veterinary Medicine and Animal production,

Sudan University of Science and Technology, Khartoum North

\title{
SERUM BIOCHEMICAL VALUES OF SUDANESE STABLED AND GRAZING CAMELS (CAMELUS DROMEDARIUS)
}

(With One Table)

By

\section{S.A. ALI; S.A. OMER.; S.M. EL BASHIR; I.Y. TURKEY and SE.M. BARAKAT}

(Received at 23/1/2008)

\section{SUMMARY}

In this study, the concentrations of some blood biochemical constituents were determined in a group of 12 stabled and 12 naturally grazing camels. All animals have been subjected to careful clinical and laboratory examinations to ensure their healthy status. A significant variation was observed in serum glucose $(\mathrm{P}<0.01)$ concentration and in serum uric acid concentration $(\mathrm{P}<0.05)$, between the blood of the two groups. The stabled animals obtained the highest glucose concentration while the grazing animals obtained higher uric acid value than the stabled group. No significant variation was observed in the mean values of total protein, albumin, urea, uric acid, total bilirubin, creatinine, ALT, AST or ALP. The values obtained in this study were compared with the findings reported by other workers in camels.

Key words: Blood Biochemical constituents, camels.

\section{INTRODUCTION}

It has been shown by many workers that the composition of camel's blood was affected by seasonal, age and sex variation (Musa \& Mukhtar 1982). During the last several years there has been a change in the methods of camel keeping in Sudan. Establishment of small camel farms around big cities is rapidly growing with support from the local agricultural and veterinary authorities. The causes of this change are climatic factors, shrinkage of grazing land, diseases and the need for low price meat and milk (Mokhtar and EL-Hisanonein, 1998 \& Babiker, 2000). Raising edible animals with low - price meat, such as camels is 
one way of bridging the gap between the demand for meat and the poor purchasing power (FAO, 1995). Several studies have shown that camels are good source of milk and they constitute the most important sources of meat in arid areas (Knoess, 1977 \& Farah et al., 1992).

Haematological and serum biochemical values can be useful for evaluating the health of the population of captive and free - living camels. Haematological and serum biochemical values for Sudanese camels have been studied by many author (Hassan et al., 1968, Eldirdiri et al., 1987 and Wahbi et al., 1980). However, the information is fragmented and incomplete because the origin (captive or free - living), sex and age, or diet of the animals was not indicated.

The objective of this study was to determine normal serum biochemical values for a population of grazing camels and comparing them with that of stabled camels. Also using the obtained data as a reference values for grazing and stable camels in Sudan.

\section{MATERIALS and METHODS}

\section{Animals:}

A total of 48 blood samples were obtained from twelve, twoyears old, male camels which were grazing naturally in the area of Abu Deleig (North-east of Khartoum town). A further 48 blood samples were obtained from twelve, two-years old, male camels housed in open sheds at the College of Veterinary Medicine \& Animal Production, Experimental Farm. The camels were kept on a roughage concentrate mixture (containing molasses) to satisfy their growth requirements. All animals have been subjected to careful clinical and laboratory examination to ensure their healthy status according to Manefield (1996)

\section{Blood sampling and analysis:}

Blood was collected by jugular venipuncture using vacutainers, firstly by using tubes containing sodium flouride oxalate for plasma glucose level and the second serum samples were obtained by vacutainar without anticoagulant and centrifugation of the blood for $10 \mathrm{~min}$. at $2500 \mathrm{rpm}$, and were stored at $-20^{\circ} \mathrm{C}$ for later analysis. Glucose was determined immediately in the fluorinated blood plasma.

Colorimetric methods were adopted for the determination of serum concentration of glucose, total protein, albumin, urea, uric acid, total bilirubin, creatinine as well as the activities of the enzymes alanine aminotransferase (ALT), aspartate aminotransferase (AST) and alkaline phosphatase (ALP). using standard biosystem and Plasmatec diagnostic 
kits were estimated with a Spectrophotometer (Unicam-8625 UV), for the analysis of serum samples.

\section{Statistical Analysis:}

Data were analyzed by student t-test using SPSS.

\section{RESULTS}

Table 1: Concentrations of some blood biochemical constituents in stabled and grazing camels

\begin{tabular}{|l|c|c|}
\hline \multicolumn{1}{|c|}{ Variables } & $\begin{array}{c}\text { Grazing group } \\
\text { (Mean } \pm \text { S.D. })\end{array}$ & $\begin{array}{c}\text { Stabled group } \\
\text { (Mean } \pm \text { S.D. })\end{array}$ \\
\hline Glucose $\mathrm{mg} / 100 \mathrm{ml}$ & $92.44 \pm 26.61^{* *}$ & $143.42 \pm 56.42$ \\
\hline Total protein $\mathrm{g} / 100 \mathrm{ml}$ & $7.13 \pm 0.39$ & $7.02 \pm 0.62$ \\
\hline Albumin $\mathrm{g} / 100 \mathrm{ml}$ & $3.34 \pm 0.23$ & $3.27 \pm 0.33$ \\
\hline Urea $\mathrm{mg} / 100 \mathrm{ml}$ & $25.29 \pm 2.2$ & $24.96 \pm 1.9$ \\
\hline Uric acid $\mathrm{mg} / 100 \mathrm{ml}$ & $3.04 \pm 0.49^{*}$ & $2.82 \pm 0.29$ \\
\hline Creatinine $\mathrm{mg} / 100 \mathrm{ml}$ & $1.21 \pm 0.13$ & $1.22 \pm 0.13$ \\
\hline Total bilirubin $\mathrm{mg} / 100 \mathrm{ml}$ & $0.19 \pm 0.02$ & $0.21 \pm 0.01$ \\
\hline ALT Iu/L & $9.94 \pm 3.06$ & $9.84 \pm 2.0$ \\
\hline AST Iu/L & $25.67 \pm 3.06$ & $25.34 \pm 2.56$ \\
\hline ALP Iu/L & $85.06 \pm 1.1$ & $84.6 \pm 2.33$ \\
\hline
\end{tabular}

** *Highly significant at $(\mathrm{P}<0.01)$

*Significant at $(\mathrm{P}<0.05)$

The mean \pm standard deviation of the studied biochemical parameters are presented in Table 1 . Serum glucose concentration of stabled camels was significantly higher $(\mathrm{P}<0.01)$ than that of grazing ones. In contrast, uric acid concentration of the stabled animals was lower $(\mathrm{P}<0.5)$ than that of the grazing ones. No significant variation was observed in the concentration of the rest studied parameters.

\section{DISCUSSION}

The stabled animals showed a remarkable increase in mean serum glucose value when compared with the grazing ones. This agrees with Mirgani and Bakhit (1987) who found a distinct increase in camel blood glucose level two hours post feeding molasses. This high glucose level was attributed to an increased production of propionic acid which is the main gluconeogenic substrate in fed ruminant, and / or due to some molasses escaped fermentation and digested post ruminally leading to increased gluconeogenic activity.

El Mahdi et al. (1997) performed a glucose tolerance test in camels, ponies and goats. Camels showed the highest plasma glucose 
level. They concluded that camels tissues may be less responsive to insulin.

The serum glucose concentration of the stabled animals was higher than that obtained in Sudanese camels (Mirgani and Bakhit 1987, El Bagir 1992 and Uro 1997) and in Iranian camels (Shaheen 2001). Serum glucose level in the grazing animals compares favorably with the findings of the above mentioned researchers.

The high value of serum uric acid concentration obtained by the grazing animals may be due to the fact that camels at their natural habitat try to save the nitrogenous compounds for biosynthesis of proteins. The mean uric acid values of the two groups are close to that obtained by Haroun, (1994).

Both groups showed similar values for serum total protein and albumin. This is in accordance with the finding of El Bagir, (1992) who concluded that camel's serum total protein and albumin do not vary with the nutrients. The mean serum total protein of this study compares favorably with that found by other researchers for camels, in Sudan (Abdel Gadir et al, 1979 and Mirgani, 1980), and in Iran (Tabatabaei and Nazifi, 2001). The mean total protein value of this study is much lower than that reported by Abbas and Musa, (1989) and by Hassan et al., (1968) for Western Sudan camels living at their natural habitat. However, the mean serum total protein value of this investigation was higher than that found in Sudan (El Bagir, 1992) and in Iran (Shaheen, 2001). Mean albumin value of this study lies within the range of the Najdi camels (Haroun, 1994), but is higher than the values found in Sudan, (Abdel Gadir, 1979 and Mirgani, 1980) and in Saudia Arabia (Elsebaeih, 2006).

Mean serum urea level of this work is within the lower limit of Najdi camels (Haroun, 1994). But seems to be lower than the values obtained by Mirgani and Bakhit, (1987), and is higher than the values of Shaheen, (2001) and Badawy, (2006). This variation in the camel serum urea content can be attributed to the fact that ruminants, kept on a low protein level, can cycle blood urea back to the rumen, via saliva, for biosynthesis of proteins.

Mean serum value of creatinine is lower than that obtained by Badawy, (2006), and higher than the values of Tabtabaei and Nazifi, (2001).This variation may be attributed to variation in the animals muscular mass and/or degree of work or exercise.

Although serum total bilirubin value of this work is lower than the mean value of Najdi camels (Haroun, 1994), but it lies within their 
normal range. However, higher values were obtained by Abdel Gadir et al., (1979), and Osman and Al-Busadah, (2001).

The level of serum ALT activity shown in this study is similar to that recorded for Najdi camels (Haroun, 1994). But is much lower than the mean value of Saudi female camels and their calves (Osman and Al- Busadah, 2001). Serum mean AST activity of this study is higher than the maximum value of Najdi camels (Haroun, 1994). Higher values for serum AST activity were found in Sudan (Eldirdiri et al., 1987) and in Saudia Arabia (Osman and Al- Busadah, 2001). Serum activity of ALP compares favorably with the finding of Osman and Al- Busadah, (2001) for dry female camels. Although serum mean ALP activity was lower than the mean value of Najdi camels, it lies within the range for this breed reported by Haroun, (1994). The variation observed in the present study with regard to the measured parameters and that of other workers, can be attributed to breed, sex, environmental conditions, age, physiological status, season of the year and/or plane of nutrition.

All the values of the measured parameters lie within the normal range reported by many researchers compiled by Manefield, (1996). This is due to the wide concentration range of these parameters in the serum of camels.

\section{REFERENCES}

Abbas, B. and Musa, B.E. (1989): Studies on camel nutrition under nomadic pastoralist condition. Camel News Letter No. (5).

Abdel Gadir, S.E.; Wahbi, A.A. and Idris, O.F. (1979): A note on hematology of adult Sudanese camels. Workshop on Camel, Khartoum. Provisional Report. No. 6 P. 347-354. Stockholm: International Foundation for Science (IFS).

Babiker, S.A. (2000): Principles of Animal Production. Curriculum Administeration, Ministry of Education. Khartoum, Sudan.

Badawy, M.T. (2006): Seasonal changes in some hemato-biochemical values in mature one humped she-camels in the north-western of Egypt. Proceeding of the International Scientific Research Conference on Camels. Kingdom of Saudia Arabia.

El Bagir, N.M. (1992): Studies on lipid and carbohydrate metabolism in camel and sheep. PhDThesis in Biochemistry. University of Khartoum, Sudan.

Eldirdiri, N.1.; Suliman, H.B. and Shommein, A.M. (1987): Normal serum activities of some diagnostic enzymes in dromedary camel in Sudan. Vet, Res, Comm. 11: 201-203. 
El-Mahadi, B.; Sallmann, H.P.; Fuhrmann, H.; Von Engelhardt, W. and Kaske, M. (1997): Comparative aspects of glucose tolerance in camel, sheep and ponies. Comp Biochem Physiol (A) 188, 14751.

El-Sebaieh, A. (2006): Electrophoretic pattern of blood serum protein in single -humped camel (Camelus dromedarius). Proceeding of the International Scientific Research Conference on Camels. Kingdom of Saudia Arabia.

FAO (1995): Food and Agriculture Organization, Quarterly Bulletin of statistics. UN Rome 8: 31-36.

Farah, Z.T.; Rellenmayer, R. and Atkins, D. (1992): Vitamin content of camel milk. Int. J. Vit Nut. Res. 62: 30-33.

Haroun, E.M. (1994): Normal concentration of some blood constituents in young Najdi Camels (Camelus dromedarius). Comp. Biochem. Physiol. (A) 108, 619-622.

Hassan, Y.M.; Hoeller, H. and Hassan, I.M. (1968): Observation on the blood constituents of camels in the Sudan. Sud. J. of Vet. Sci. and Anim. Husb.9, 464-474.

Knoses, K.H. (1977): The camel as milk and meat animal. World Anim. Rev. 22, 39-44.

Manefield, G.W. (1996): Clinical Examination of the Camel. Camels A compendium. University of Sydney Post Graduate Foundation in Vet. Sci. Series, 22, 60-61.

Mirgani, T. (1980): Studies on lipid and carbohydrate metabolism in camel. PhD Thesis in Biochemistry. University of Khartoum, Sudan.

Mirgani, T. and Bakhit, S.A. (1987): Effect of intraruminal administration of molasses on blood glucose and rumen VFA concentration in camels, sheep and goats. Sud. J. of Vet. Sci. and Anim. Husb. 26, 47-54.

Mokhtar, M. and EL-Hisanonein (1998): Proceedings of the International Symposium Constraints and Possibilities of Ruminant Production. Cairo, Egypt.

Musa, B.E. and Mukhtar, A.M.S. (1982): Studies on the normal hemogram and some blood electrolytes in camels (Camelus dromedarius). Sud. J. Vet. Sci. \& Anim. Husb. 23, 38-43.

Osman, T.E.A. and Al-Busadah, K.A. (2001): Effect of age and lactation on some biochemical constituents of camel blood in Saudia Arabia, Journal of Camel Practice and Research, 7,149-152. 
Shaheen, H.M. (2001): The effect of feed and water deprivation on ingestive behaviour and blood constituent in camels: comparison with sheep and goats. Journal of Camel Practice and Research. 8, 153-162.

Tabatabaei, A. and Nazifi, S. (2001): Biochemical and Cytological Properties of Blood and Peritoneal Fluid in Clinically Healthy Adult Camels. (Camelus dromedarius). Journal of Camel Practice and Research. 8, 123-126

Uro, A.O. (1997): Carbohydrate of camel with special reference to source of blood glucose. Camel News Letter No.(13) (ACSAR)

Wahbi, A.A.; Abdel Gadir, S.E. Neimat and Idris, O.F. (1980): Plasma electrolytes and minerals of camel in the Sudan. Provisional Report. No. 6 P. 355-364. Stockholm: International Foundation for Science (IFS). 